\title{
Language Maintenance at the Javanese Family in Bukit
} Malintang District

Sudarti Rahayu Ningsih ${ }^{1}$ \& Lenni Marlina Harahap

Corresponding Author: Sudarti Rahayu Ningsih, English Applied Linguistics Study Program, Postgraduate School, State University of Medan, Jl. Willem Iskandar Pasar V, Kenangan Baru, Percut Sei Tuan, Kabupaten Deli Serdang, Sumatera Utara - Kotak Pos No. 1589 - Medan 20221 Indonesia. Tel: 62-8227783-7011. E-mail: yyupendraupen@gmail.com

Copyright $\odot$ Association of Language Teachers in Southeast Asia. All rights reserved

\section{INTRODUCATION}

Sidojadi is the only one pure Javanese village in Bukit Malintang district. It means that the first original tribe opened this village was Javanese. Ten years ago, this village was opened by the transmigrants from java that use Javanese as a mother tongue, but time to time this mother tongue is rivalled by Indonesia language that is used by the early family toward their children. In one side, it is good for the existence of Indonesia as national language, but tendency to use Indonesia as the vernacular language is a bad sign in maintenance Javanese language. Moreover, for the young generation that will be Javanese language speaker in the future. It means, the young generation is hoped to be able to comprehend and maintain Javanese language as the origin language that shows identity of the Javanese itself.

Besides that, Mandailing language is the language comprehended by the societies around this district included Sidojadi too. Sidojadi societies comprehend this language from intercommunication with the principle need one to another in any particular necessaries, for instance because of buy and sell interaction and intermarriage. The existence of bilingualists or multilinguslists in an area is actually a threat to the culture of the region to the local language, because it can shift or even maintain the language. In this case, there was a study about language 
maintenance. The study of language maintenance was formulated by Fishman (2013: 34) that studies about the relationship between change and stability of language use on the one hand with psychological, social, and cultural processes in anecumental society.

It was found the preliminary data from Ermalia Amna (2018) which took a research with entitle 'Mantaining Bahasa Aceh in Keude Kupi among Teenagers in Medan'. Her study focused specifically on investigating the maintenance of Bahasa Aceh by Acehnese teenagers in keude kupi in Medan. The subjects were ten Acehnese Teenagers in keude kupi in Medan. The research found that there were some factors lead to the maintenance of Bahasa Aceh, they are: language attitude, parents' role, environment, visiting homeland continuously and intra-marriage. The maintenance of Bahasa Aceh was done by keep using it to other Acehnese, read the Acehnese online or printed media and watches or listen to the Acehnese entertainment. In maintaining their mother language, the teenagers' reasons were not only about showing their identity, help their community to progress and achieving self-esteem and/or self-pride, but also to create the feel-like-home situation, since using the language with the same Acehnese peers makes them feel closer and bound.

Then, based on the direct observation of the researcher and communication with one of the public figure in society too, named BS (age 79 years old). Below was the transcript:

"Nak mbiyen, kabeh keluarga neng Sidojadi nganggo boso Jowo, yo karo wong tuo, bojo, anak-anak, yen tonggo-tonggo ne. Nak bojone wong Mendeleng pun yo nganggo boso Jowo, yo ben bojo ne sing sui-sui melu nganggo boso Jowo. Mantuku yo koyo ngono. Tapi lah kok saiki, arek-arek e sing roto-roto umuran SD podo nganggo bahasa Indonesia. Yen wong tuo ne pun ngono juga karo arek e. Sui-sui boso Jowo ne wes ra ketok mene."

He said that at the previous time, the society in Sidojadi maintain the Javanese language by the intensity of using it at home, even if they did intermarriage with the other society from different tribe, their couple would learn Javanese language too and by the time would use Javanese as their daily language at home. It can be said that language still can be maintained, but contrary for their children, nowadays their children use Indonesia as their daily life for the average in primary school degree.

Based on the previous research and observation above, the researcher is interested to investigate the types of language maintenance of the family and children, the factors of language maintenance, and the reason that makes the family and children can and cannot maintain Javanese language as mother tongue in daily life. It means that it was found that the hope/expectation to the young generation that comes from the family is not suitable with the reality gotten from the observation result.

This research has a contribution as theoretically as the reference for the authors that build art gallery in maintain Javanese language. Then, practically this research is expected useful as the reference for other researchers which make a research about language maintenance especially for Javanese, and to give the description and suggestion especially for the village government and language observer. So, for next time Javanese language maintenance can be applied more.

\section{LITERATURE REVIEW}

\subsection{Javanese Family}

\subsubsection{Family}

A country, even the smallest unit of it, like a village, will not stand without a community as its inhabitants. The community, that usually called by society has a smallest primary group. Such in Marnoto (2007: 16) argument,

Family is the smallest primary group of the society. Pure family is the one social unity include to the husband, wife, and children. Meanwhile, a big family is the group unity and marriage relation covered by the family from the father and mother include to the grandfather, grandmother, uncle, aunt, in-laws, and cousin. 
As we know, children get the education firstly in the family, include to the mother tongue acquisition. So that, parents should be able to effort their children developed reasonably. In this case, parents' status holds an important role because the habitual actions of the children are influenced by parents' social status. Simply, in Indonesia society, there is a status based on the occupation, such as farmers' family, employees' family, traders' family, and entrepreneurs. Big or small family influences language acquisition. In the big family, children have a big chance to socialize with their families. They learn to receive other's opinion, respect to the other, and try to express their opinion by using language. Family is the first and main place for the children learnt about language.

Children know language from their parents firstly. The person who teaches language firstly in the family is a mother, so that the first language is called as mother tongue. If the parents teach Javanese language firstly since their children recognize language, so it will be comprehended by them as their mother tongue. In the family, parents educate their children through the norms, attitudes, customs, or the other social skills use language as the main vehicle. Meanwhile, in a small family, children has more limited chance to do the interaction with their family, but it can be overcome by increasing their intercommunication with playing friends in the society. Children acquire many speech experiences from their friends around the society.

\subsubsection{Javanese}

In anthropology, Javanese society is the people who live and use Javanese language in their daily life with various dialects hereditary. Javanese societies are they who live in central java and east java, or both of them. Geographically, Javanese lives in Java Island include to Banyumas, Kedu, Yogyakarta, Surakarta, Madiun, Malang, and Kediri. Meanwhile, out of that area is called coastal area. Javanese societies are the society unit tied by life norms because of history, tradition, and religion. It can be seen from Javanese characteristics as the whole. Kinship life system in Java was drawn in Javanese genetic relationship.

Rachim and Nashori (2007: 31) state,

Javanese family walk in four main manners, there are: 1) has an attitude suitable to the each degree and respect the position one to another, 2) express something indirect through "sanepo" or figuratively, 3) respect to the individual things such as do not know individual problem, 4) avoid utterances or attitudes that show inability to control self by using harsh words directly.

We can see that Javanese not only lives in java now, but also in several provinces, such as in Lampung, Jakarta, Sumatera Utara, Riau, South Sumatera, Banten, and East Kalimantan. It is caused by redundancy of population, decrease of working area, and transmigration in colonialism.

\subsection{Language Maintenance}

\subsubsection{The Nature of Language Maintenance}

Mesthrie (1999: 42) defines, "Language maintenance as the continuing use of a language in the face of competition from a regionally and socially powerful or numerically stronger language." It is said that the presenting here as the reverse side of language shift: that is, change from habitual use of one's minority language to that of a more dominant language under pressures of assimilation from the eminent group.

Then, based on the Sumarsono and Partana (2004: 231) in language maintenance,

Friendly defined collectively to continue in using the habitual language. When the utterance of friendly started to choose new language in the domain that before for the old language, it is one of the possibility that sign of the shift is being happened. If the society is monolingual and collectively did not want another language, they maintain the language pole used by them clearly. But, language maintenance is often to be characteristic of bilingual and monolingual. First, if the friendly is diglossic: friendly is come for a certain domain in every language in order the domain limit a language did not exceeded by the other languages. 
It is intended that the language maintenance is happened in the language society that still uses their language on the language utilization domains that comprehended by language speaker traditionally. Usually, language maintenance assessment leads to the relation between changing or stability of the language habit with psychology, social, and culture processes are being happened when the different language society do the interaction with another.

Language maintenance is one of the bilingual or multilingual unique characteristic that can be happened in diglossic society, they are the society that maintains to use several languages based on the dynamics of language use society and its relation toward the development of social, politics, economic, and society culture. Most of the language maintenance is defined by society vulnerability toward industrialization, urbanization, political of national language, and mobility degree from the members of language society.

\subsubsection{Language Maintenance Types}

Siregar (1998: 14) explains,

There are two types of language maintenance; they are active language maintenance and passive language maintenance. Active maintenance has relation almost one opposite one among language with social context.

It means, speech society differ language based on the two or several signs of attitude value and language behaviour that do not overlap. This language use is happened without code switching and code mixing. Then, Siregar (1998: 14) adds, "Passive maintenance is language society characteristic that has value and attitude does not overlap." It means society feels that their region language as the ethnic identity sign. In another word, society does not use the region language regularly suitable with the function as regional sign. This passive maintenance is caused by code switching and code mixing.

\subsubsection{Language Maintenance Factors}

Sumarsono (1993: 17) says that one important factor in the language maintenance is the loyalty of its supporters. It can be said that by the loyalty, the supporters of a language will still pass on its language from generation to generation. Then, Ekoyantiasih (2008: 30) explains that the prestige of a language is one of the survival factors of a language. In addition to prestige, she also explains the existence of social networking factors. This means that the bond between members of the community said in a familial relationship, such as relationships between families, relations between neighbours, the similarity of belief/religion, ethnic similarity, language pride, and the value of cultural/ social norms.

\subsubsection{Reasons of Language Maintenance}

According to Crystal (2003) language maintenance should be done in order to (a) create cultural diversity, (b) keep ethnic identity), (c) enable socio adaptability, (d) increasing security for the children psychologically, and (e) increase the sensitivity of linguistic. We can states that five terms above are related one to each other, for example when certain language is maintained, of course the identity of language users also maintained and automatically the language will form the cultural diversity.

The maintenance of vernacular language is very important, because language shows the ethnic identity. As Holmes (2001: 158) stated that where language is considered as important symbol of a minority group's identity, the language is likely to be maintained longer. It means that the language can be maintained continuously; when a society still considers that their language is their group's identity and important symbol for their existence recognition.

\section{METHOD}

This study was conducted by using descriptive qualitative method. Bogdan and Biklen (2007: 3) say that qualitative research is frequently called naturalistic because the researcher frequents places the event he or she is interested in natural occurs. It means, qualitative research describes and interprets what it is concerning with condition or relationship that exist, opinion that are held, processes that are going on, what data shows, effect that are evident, or trends that are developing. 
This study used case study approach where Ary, Jacobs, and Sorensen (2010: 29) argued that a case study is a type of ethnographic research study that focuses on a single unit, such as one individual, one group, one organization, or one program. The goal is to arrive at a detailed description and understanding of the entity (the "case").

The data of this research was the intensity of using utterances of Javanese language in transcript of the interview to the Javanese family in language maintenance. The data sources of this research were SD family, as intermarriage Javanese family. They came from Sidojadi village, Bukit Malintang sub-district, Mandailing Natal Regency, Sumatera Utara. They came from farmer family with education background from senior high school, had 4 children that used Javanese as their daily language, except for the fourth child that used Indonesia as his daily language.

Instruments of data collection were observation, interview, and audio video recorder. Kothari (2004: 96) said that observation was the most commonly used specially in studies relating to behavioural sciences by serving a formulated research purpose with systematically planned and subjective checking and control. Then, interview was a conversation between interviewer and interviewee as the data source to get certain information. In addition is audio-video recorder. Using audio-video recorders during interviews raises some special considerations for implications to the researcher-informant relationship. When chooses to use an audio-video recorder, researcher asks respondents if they mind. The point in the encounter where researcher asks permission can be touchy. Never record without permission, although some informants simply will not care if the interview is recorded.

Technique of collecting the data were: 1) observation, it was applied to ensure whether the participants maintain their Javanese language in daily conversation. The researcher went to the site and observed the participants in their daily activity whether they still use Javanese language or not; 2) interview which was done to know the language maintenance and its factors in the Javanese family particularly from the parent to the children in Bukit Malintang district, a case study was in Sidojadi village. Interview was included to the information about informant identity and transcript of the interview about language maintenance in Javanese family; 3 ) and audio video recorder, in here the researcher took some pictures and video to help a long interview, because the researcher might not down notes to supplement her memory, or sometimes subjects would try to change their minds as they begin talking.

The processes of analysing the data were based on Miles, Huberman and Saldana (2014) with the phases: 1) Data condensation consists of the process of selecting, focusing, abstracting, simplifying and transforming. It was aimed at the procession the raw data that appear in the written-up field notes in order to be analysed. The four steps of the process of data condensation are: (a) Selecting interview based on the factors and type of language maintenance; (b) Simplifying with the meaning to make the data simpler or easier to understand; (c) Abstracting, means to consider the data theoretically or separately; and (d) Transforming, means to make a through or dramatic change in the form and appearance. Then, 2) Data display, the researcher displayed the data from data condensation to list the factors of language maintenance and find the type of language maintenance. The last, 3) Conclusion drawing/verification, researcher developed conclusions regarded to the study.

\section{RESULTS AND DISCUSSION}

\subsection{Results}

In the research was tried to take the data by using interview about language maintenance among Javanese family. The data was taken from SD Family. Below were the transcripts of SD' wife and SD utterances:

"Lantaran kakang, bapak, mamak, karo mendiang mbah nganggo boso Jowo teros, yo ket omah-omah iyukmu teros ngerungokne boso Jowo. Jadi, sui-sui ngerti dewe. Pelan-pelan belajar nganggo boso Jowo, yo menpun ndisek e rodo kaku. Nak eneng sing ra ngerti yo kakang ajari, lantaran nak ra iso piye arep melu ngomong. Yen dibiasane sui-sui yo iso juga." 
Based on the transcript above SD said that he used Javanese language to his wife since he married her. All of family's members, such father, mother, moreover grandmother that was only knew Javanese language, certainly use Javanese language in the family area and in the society, if his wife could not use that language, it would difficult for her to do the interaction. Finally, time to time and slowly she could master and use Javanese language until now. It could be said that although SD did intermarriage with wife came from Mandailingnese, he could maintain Javanese language and his wife followed him with involved helping from his family's members such his father, mother, and grandmother.

That was suitable to the language maintenance theory from Mesthrie (1999: 42), where the language maintenance happened as the continuing use of a language in the face of competition from a regionally and socially powerful or numerically stronger language. Then based on the Siregar (1998: 14), language maintenance was happened in the language society as the active language maintenance type, in which is still used their language on the language utilization domains that comprehended by language speaker traditionally.

Because of Javanese language was strong in SD family, SD tried to apply it to his wife. SD could maintain his language and kept the existence of his language, so his wife followed him. Although Mandailing language was a language used in the district or region, but because of SD's wife lived in Javanese language that used Javanese all the time as their mother tongue, so Javanese language to be stronger and it was used by SD' wife to do the interaction with her new family.

So, from the theory of Crystal (2003), it was clear that language maintenance happened in the SD Family to keep ethnic identity that came from family such as father, mother, and grandmother that was very keep of their Javanese language as the mother tongue. Then the theory was also focused to one of the important factors in the language maintenance, it was the loyalty of its supporters (Sumarsono, 1993: 17). With that loyalty, the supporters of a language will still pass on its language from generation to generation. So, SD family's big loyalty made them could maintain Javanese language actively.

Then, the second transcript was:

"Kakang nduwe anak papat, kabeh diajari boso Jowo. Tapi leng paling cilik, si B malah ra nganggo boso Jowo. Apalagi ket mbah ninggal, ra eneng sing nyeneni nak ra nganggo boso Jowo. Yo sak tenane diajari boso Jowo juga ket belajar ngomong, tapi bar ngerti ngeluyur karo konco-koncone sing kokean nganggo bahasa Indonesia, sui-sui B malah nganggo bahasa iku, waktu kira-kira umur rong taonan lah. Umor sak ono bocah kan gampang niru-niru bahasa, endi sing sering dirungokne yo iku sing diinget. Jadi, urong sempet lancar boso Jowo. Kakang mikire, daripada bocah e bingung, yo ra popo lah nganggo bahasa Indonesia, awak ngikuti paling ora karo de e tok. Bahasa Indonesia mbesok perlu juga neng sekolah, pokok e diingetno nak boso Jowo iku tetap boso asal e awak."

SD had four children, but from all of them, the fourth child, called B could not use Javanese language. He talked in Indonesia, and all of family also used Indonesia to do the interaction with him. Firstly, B got Javanese language from his parent in language acquisition, but since B could do the interaction with his friends out of home and all of his friends used Indonesia, so he followed them too. Moreover, the grandmother had died, so there was no person angry to them when they did not use Javanese for daily communication in family area. For a child with age about 2 years old, it was easy to follow language from his surrounding, so he used language from the side the frequency of using and listening by him. Before he mastered one language fluently, his language could be changed. With any considerations, particularly to B, SD family do the communication in Indonesia in order B did not be confused. SD talked to B that now in fifth grade of elementary school which Javanese language was their origin language. So, whatever the reason, B should be proud of it.

The case above was supported by the language maintenance theory from Sumarsono and Partana (2004: 231) where friendly defined collectively to continue in using the habitual language. When

SALTeL Vol. 2, No. 1, 2019: $11-18$ 
the utterance of friendly started to choose new language in the domain that before for the old language, it is one of the possibility that sign of the shift is being happened.

B could not maintain his original language. His language was shift to Indonesia because of changing from the environment, in this case in friendly area. Besides that, the frequency and dominant using of Indonesia language made him applied Indonesia in daily life. In consideration, B did the passive language maintenance based on the theory of language types from Siregar (1998: 14), with the characteristic society felt that their region language as the ethnic identity sign. Altought B did not use Javanese language suitable with the function; he still knew that Javanese language as a region sign. In another word, society did not use the region language regularly suitable with the function as regional sign. This passive maintenance was caused by code switching and code mixing. Then, the case was suitable to the theory of language maintenance factors that came from the prestige for a language from Ekoyantiasih (2008: 30) as one of the survival factors was implanted by SD to B to always remembered his ancestry.

\subsection{Discussion}

In line with the previous research which was conducted by Ermalia Amna (2018) which took a research with entitle 'Mantaining Bahasa Aceh in Keude Kupi among Teenagers in Medan'. Her study focused specifically on investigating the maintenance of Bahasa Aceh by Acehnese teenagers in keude kupi in Medan. The subjects were ten Acehnese Teenagers in keude kupi in Medan. The research found that there were some factors lead to the maintenance of Bahasa Aceh, they are: language attitude, parents' role, environment, visiting homeland continuously and intra-marriage. The maintenance of Bahasa Aceh was done by keep using it to other Acehnese, read the Acehnese online or printed media and watches or listen to the Acehnese entertainment. In maintaining their mother language, the teenagers' reasons were not only about showing their identity, help their community to progress and achieving self-esteem and/or self-pride, but also to create the feel-likehome situation, since using the language with the same Acehnese peers makes them feel closer and bound.

Then, Lailatus Shoimah (2017) from State Surabaya University entitled Madura Language Maintenance in Kramat Village of Mangare Island which discussed about Madura language as language phenomenon was used by community as daily communication language. This case also included to language maintenance which was the goal to describe Madura language maintenance in Kramat Village that stand on one of the Javanese islands, it was Mangare Island. The research was looked from family, education, and occupation domains and factors of language maintenance. From the result it was found that Madura language still could be maintained and used by the society in Kramat village involved family, education, and occupation domains. Then, the factors of language maintenance were loyalty, prestige and social networking that same enough to this research.

\section{CONCLUSION}

It can be concluded that language maintenance in Javanese family in Sidojadi village for SD and his wife case is based active language maintenance type, based on the factor of loyalty of the origin society to maintain its language although it face competition with the Mandailing language as the common language in Bukit Malintang district caused by intermarriage. And also with the reason to keep ethnic identity that was very keep their Javanese language as the mother tongue. Meanwhile, it does not happen to their fourth child, named B. B uses Indonesia language evenly is gotten from environment out of home and the friendship with peer friends. B just knows that Javanese language as their origin language should be prestige as the history.

Besides that, the researcher suggests to the society members of Sidojadi village in Bukit Malintang district to be able to apply more and add the intensity to use Javanese language in the family. Although the children used Indonesia language, the parent should response with Javanese, in order by the time children follow the parent, do not parent follow their children even though parent. Then, it is hoped to the village government to do some activities that can live Javanese language again around the society and make society do not forget their language history. The activities such as set up art gallery first, where there the young generation learn about Javanese history, language, 
and culture. Then, stage performing art like drama by using Javanese language, practice young generation to be able to be puppeteer in puppet and leathered horse performances, and speak in Javanese in every chance of cultural programs.

\section{ACKNOWLEDGEMENTS}

The researcher thanks to all respondents for being so kind and cooperative to response and answer every question given in interview during the data collection process of this study. In addition, thanks also to the editors and reviewers for their comments and suggestions that were useful in the earlier version of this article.

\section{REFERENCES}

Amna, E. 2018. Maintaining Bahasa Aceh in Keude Kupi among Teenagers in Medan. Jurnal Linguistik Terapan Pascasarjana Unimed, 15 (1): 8-14. ISSN 2407-7410

Ary, D., L.C. Jacobs, \& C. Sorensen. 1979. Interaction to Research in Education. New York: Holt, Rinehart and Winston.

Bogdan, R.C., \& S.K. Biklen. 2007. Qualitative Research for Education: An Introduction to Theory and Methods, $5^{\text {th }}$ ed. Boston: Pearson Education.

Crystal, D. 2003. Language Death. Cambridge: Cambrige University Press.

Ekoyanantiasih, R. 2008. Pemertahanan Bahasa Daerah Jawa di Kelurahan Depok Jaya. Depok: Universitas Indonesia.

Fishman, J.A. 2013. The Handbook of Bilingualism and Multilingualism, Second Edition. Blackwell.

Holmes, J. 2001. An Introduction to Sociolinguistcs. Essex: Pearson Education.

Kothari, C. R. 2004. Research Methodology. Jaipur: new Ade International (P) Limited.

Marnoto. 2007. Penggunaan Bahasa dalam Ranah Keluarga Muda Jawa di Kabupaten Blora, Thesis. Semarang: Universitas Negeri Semarang.

Mesthrie, R.1999. Fifty ways to say 'I do': Tracing the origins of unstressed do in Cape Flats English. South African lournal of Linguistics, 17(1), 58-71.

Miles, M.B., A.M Huberman, and J. Saldana. 2014. Qualitative Data Analysis: A Methods Sourcebook, $3^{\text {rd }}$ edition. California: SAGE.

Rachim, R.L., \& H.F. Nashori. 2007. Nilai Budaya Jawa dan Perilaku Nakal Remaja Jawa (Java Cultural Value and Naughty Behavior Java Adolescent. Indigenous, Jurnal Ilmiah Berkala Psikologi, Vol. 9, No. 1, Mei 2007: 30-43.

Shoimah, L. 2017. Pemertahanan Bahasa Madura di Desa Kramat Pulau Mangare Kecamatan Bungah Kabupaten Gresik (Kajian Sosio Linguistik). Jurnal Sapala, Vol. 3, No.2 (2017).

Siregar, B.U. 1998. Pemertahanan Bahasa dan Sikap Bahasa. Jakarta: Pusat Pembinaan dan Pengembangan Bahasa, Depdikbud.

Sumarsono, \& P. Partana. 2004. Sosiolinguistik. Yogyakarta: Sabda. 